\title{
En el tiempo del COVID-19
}

Dr. Horacio Miscione

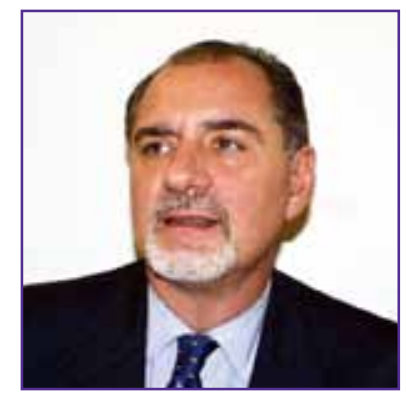

Buenos Aires de 1925 nos regalaba una apacible tarde. Con brisa leve, tal como para festejar un noviazgo otoñal.

Con paso firme y sin apuro, dos hombres cruzaban la Avenida Córdoba desde la Facultad de Medicina.

A esa hora, la Facultad estaba enmarcada por un frontispicio único, ya que el sol le dibujaba los relieves asimétricos.

Miguel de Unamuno y Teófilo Villegas conversaban animados, pero el mayor tenía en el entrecejo una arruga poco usual. Ella solo se le dibujaba por un acontecimiento fortuito reciente.

El más joven se dirigía a él con pasión:

- Don Miguel, confiemos en la tecnología y en la ciencia. Un ejemplo es este tranvía, diestro y útil, que hace vibrar el adoquinado.

- Puede ser amigo Villegas, pero le aconsejo pensar que si bien el tranvía es un desarrollo tecnológico fantástico, siempre lo importante y único es la vida. Sin duda, recuerde que lo importante siempre es la vida.

En 1956, el tranvía había cambiado. Era ya un desarrollo prodigioso. En tanto que la vida seguía siendo un ciclo biológico inalterable. Único y fatal.

Aquellos que logramos sobrevivir ciertas décadas, sabemos de la epidemia de polio del 56. En ese momento, la epidemia solo hallaba una supuesta mitigación con la acaroína en las veredas y la cal en los árboles.

Los niños llevábamos como ofrenda a Heiden y a Medin, pedacitos de la madera del árbol alcanforero guardados en un escapulario, que más que eso era un pectoral ignorado. Obviamente que este artefacto aromatizador desconocía tanto a los virus como a las bacterias.

Hoy en día, con nuestra pandemia de coronavirus, también existe la demonización de la enfermedad, ignorando que, en realidad, es tan sólo un microorganismo compuesto de material genético.

Este activo virus comparte, en el devenir biológico, el mismo espacio que los humanos.

Es muy posible que quien lea esto recordará la "Hierba de los Caminos", una de las canciones de la guerra civil española, "que culpa tiene el tomate...". La baraja del tomate podría cambiarse por la del COVID-19 y la canción cerraría igual.

Los traumatólogos sabemos de los miedos y sabemos qué importante es la vida como parte de este ciclo que comenzó con nacer. Vemos que la compensación de la escala zoológica hace que ahora los zorros aparecen como recuperando espacios en las ciudades vecinas a una colina y las ratas enardecidas pululan en los hábitats de los humanos.

Dr. HORACIO MISCIONE • horamisc@ fibertel.com.ar

Cómo citar este artículo: Miscione H. En el tiempo del COVID-19. Rev Asoc Argent Ortop Traumatol 2020;85(2):95-96. https://doi.org/10.15417/issn. 1852-7434.2020.85.2.1089 
La AAOT apoya con consejos, porque sabe que el miedo es un paciente prematuro de mal pronóstico y las verdades mediáticas tienen baja vida media.

Si el COVID-19 lo decide en su andar rápido e intrépido, los traumatólogos deberíamos poseer ya un Valhalla ortopédico.

Durante el día, estaríamos dispuestos a corregir deformidades, consolidar fracturas, modificar articulaciones.

Por la noche, celebraríamos los éxitos propedéuticos y terapéuticos, para retomar todo el ciclo el próximo siguiente día. 